\title{
FAKTOR-FAKTOR YANG MEMPENGARUHI ETOS KERJA PEGAWAI KECAMATAN SIDOREJO SALATIGA
}

\author{
Diyah Fitriyani ${ }^{1}$, Ocky Sundari ${ }^{2}$, Johnson Dongoran ${ }^{3}$ \\ ${ }^{1,2,3}$ Fakultas Ekonomi dan Bisnis, Universitas Kristen Satya Wacana Salatiga \\ e-mail: diahfitri1996@gmail.com
}

\begin{abstract}
Abstrak
Jenis penelitian ini adalah deskriptif kualitatif dengan tujuan untuk mengetahui gambaran dan faktor-faktor yang mempengaruhi etos kerja pegawai Kecamatan Sidorejo Salatiga. Subjek dalam penelitian ini adalah seluruh pegawai Kecamatan Sidorejo Salatiga yang berjumlah 14 orang, penelitian ini dilakukan dengan wawancara mendalam yang kemudian data dianalisis dengan distribusi frekuensi. Berdasarkan hasil analisis data, dapat disimpulkan bahwa pegawai kecamatan memandang etos kerja sebagai suatu sikap positif yang muncul dari kesadaran individu yang kemudian di implementasikan kedalam pekerjaan agar memperoleh hasil yang maksimal. Untuk faktor-faktor yang mempengaruhi etos kerja untuk kategori gaji pegawai merasa gaji mempengaruhi etos kerja karena gaji merupakan komponen utama dalam bekerja. Untuk kategori agama pegawai mengatakan agama mempengaruhi etos kerja sebab agama dijadikan pedoman hidup dan juga kerja. Untuk kategori disiplin pegawai mesara disiplin mempengaruhi etos kerja dengan penerapan disiplin akan membentuk kepribadian pegawai lebih baik. Untuk kategori tingkat sosial politik para pegawai kecamatan mengatakan tidak mempengaruhi etos kerja karena sebagai pegawai negeri sipil harus bersikap netral. Selanjutnya untuk kategori kondisi lingkungan pegawai merasa kondisi lingkungan mempengaruhi etos kerja dengan kondisi lingkungan yang nyaman tentram dalam melalukukan pekerjaan menjadi lebih fokus. Untuk faktor yang mempengaruhi etos kerja dengan kategori tingkat pendidikan pegawai merasa tingkat pendidikan mempengaruhi etos kerja. Untuk kategori struktur ekonomi pegawai merasa struktur ekonomi mempengaruhi etos kerja dengan adanya penambahn gaji pemberian insentif pegawai akan bekerja lebih keras lagi. Dan yang terakhir untuk kategori motivasi pegawai merasa mempengaruhi etos kerja artinya dengan adanya motivasi dari orang terdekat akan semangat bekerja.
\end{abstract}

Kata kunci : Kecamatan Sidorejo Salatiga, Etos Kerja.

\begin{abstract}
This type of research is descriptive qualitative with the aim to find out the picture and the factors that influence the work ethic of the Sidorejo Salatiga District employees. The subjects in this study were all employees of Sidorejo Salatiga Subdistrict, amounting to 14 people, this study was conducted with in-depth interviews and then the data were analyzed by frequency distribution. Based on the results of data analysis, it can be concluded that the sub-district employee views the work ethic as a positive attitude that arises from individual awareness which is then implemented into work in order to obtain maximum results. For factors that influence work ethic for salary categories employees feel that salary affects work ethic because salary is a major component of work. In the category of religion, employees said that religion affects the work ethic because religion is used as a way of life and work. For employee discipline category, discipline affects work ethic with the application of discipline will form a better employee personality. For the socio-political level category, the sub-district employees said that they did not influence the work ethic because as civil servants they had to be neutral. Furthermore, for the category of environmental conditions, employees feel that environmental conditions affect the work ethic with comfortable environmental conditions in doing work to be more focused. For factors that affect the work ethic with the category of education level employees feel the level of education affects the work ethic. For factors that affect the
\end{abstract}


work ethic with the category of education level employees feel the level of education affects the work ethic. In the category of economic structure, employees feel that economic structure influences the work ethic by increasing the salary giving incentives, employees will work even harder. And finally for the motivation category, employees feel that they influence work ethic, meaning that there is motivation from those closest to them to work.

Keywords : Sidorejo District Salatiga, Work Ethic.

\section{PENDAHULUAN}

Sumber daya manusia merupakan hal yang sangat penting, sebab manusia dapat dikatakan sebagai kompenen utama dalam kehidupan meskipun kemajuan teknologi berkembang dengan pesat pada ahkir-akhir. Pada kenyataannya dengan kemajuan teknologi yang semakin berkembang sekarang ini masih belum mampu menggantikan atau menggeser manusia untuk melakukan semua aktivitas dalam kehudupan di dunia (Karauwan, Lengkong, \& Mintardjo, 2015). Sutrisno (2009) mengatakan sumber daya manusia merupakan seseorang yang bekerja dalam suatu perusahaan atau instansi pemerintah yang bekerja sesuai dengan tugas dan tanggung jawabnya agar tujuan perusahaan tercapai.

Dalam rangka pembangunan dan pengembangan desa perlu adanya sember daya manusia sebagai perencana dan pelaksanaan pembangunan. Keberadaan aparatur sipil negara atau pegawai negeri sipil sebagai aparatur pemerintah dan abdi masyarakat diharapkan mampu menjalankan tugas sesuai peran dan tanggung jawabnya serta mampu memberikan pelayanan masyarakat secara adil kepada seluruh masyarakat Rakhmatullah, Hadiati, dan Setia, (2018). Aparatur sipil negara, dalam hal ini pegawai kecamatan, perlu memiliki etos kerja tinggi dalam pekerjaannya, mewujudkan tercapainya tujuan kerja kecamatan serta membantu jalanya roda pemerintahan yang memiliki tugas cukup berat dalam hal pemberian layanan memuaskan kepada masyarakat. Etos kerja yang dimiliki pegawai atau karyawan dapat dilihat dalam perilaku individu tersebut dalam bekerja seperti datang dan pulang kerja sesuai jam kerja, tanggung jawab terhadap pekerjaan, jujur, dam memiliki semangat tinggi dalam bekerja. Hal ini sejalan dengan Peraturan Pemerintah Nomor 42 Tahun 2004 tentang pembinaan jiwa korps dan kode etik pegawai negeri sipil dalam pasal 3 ayat 2 yang berisi mendorong etos kerja Pegawai Negeri Sipil untuk mewujudkan Pegawai Negeri Sipil yang bermutu tinggi dan sadar akan tanggung jawabnya sebagai unsur aparatur negara, dan abdi masyarakat (Saputa, Lengkong , \& Trang, 2018).

Karyawan dalam suatu perusahaan perlu mempunyai etos kerja dengan etos kerja karyawan tersebut akan berdampak positif terhadap perusahaan. Menurut (Rahma, Suhandana, \& Suarni, 2013) menyatakan, etos kerja merupakan totalitas kepribadian diri seseorang serta cara seseorang tersebut mengekspresikan, memandang, meyakini dan memberikan makna ada sesuatu, mendorong dirinya untuk bertindak dan meraih hasil yang optimal sehingga dengan hal tersebut dapat terjalin hubungan baik antar individu.

Menurut Tasmara (2002) ada beberapa hal penting yang berhubungan dengan etos kerja seperti: (a) Orientasi ke masa depan, (b) Menghargai waktu, (c) Tanggung jawab, (d) Hemat dan sederhana, dan (e) Persaingan sehat.

Berdasarkan Indriani (2015) "etos" diartikan sebagai pedoman atau panduan tingkah laku bagi seseorang, kelompok, institusi, maupun organisasi. Jadi, etos kerja dapat diartikan sebagai ajaran tentang bekerja yang diyakini oleh individu atau sekelompok orang sebagai hal yang baik dan benar yang diwujudkan secara nyata dan khas dalam perilaku kerja individu tersebut.

Tampubolon (2007) seseorang yang memiliki etos kerja yang cendrung tinggi harusnya dimiliki oleh semua karyawaan. Hal ini dipandang sangat penting bagi sebuah organisasi, organisasi juga membutuhkan komitmen dan kerja keras yang baik dari setiap karyawaan yang berkerja. Ketika pegawai dalam suatu organisasi tidak memiliki etos kerja yang baik maka dapat mempengaruhi menurunnya kinerja dan dampak buruknya bisa pemutusan kerja.

Berdasarkan penelitian tentang etos kerja memiliki hasil penelitian yang berbedabeda. Saputra, Lengkong, \& Trang (2018) melakukan penelitian Analisis Penerapan Etos Kerja Pada Perangkat Desa Kemang Dua Kecamatan Tompaso, mengatakan dalam penerapan etos kerja yang tepat dapat didasarkan pada motivasi, budaya, sosial 
politik, lingkungan dan pendidikan yang dimiliki oleh perangkat desa. Di sisi lain etos kerja berpengaruh terhadap peforma karyawan artinya apabila etos kerja mengalami peningkatan maka peforma perusahaan akan mengalami peningkatan (Titisari, Warso, \& Haryono, 2016). Penerapan etos kerja yang tepat akan membantu karyawan memahami bagaimana cara bekerja menjalankan tugasnya. Karyawan memahami tugastugasnya dapat menciptakan dan meningkatkan kinerja secara optimal (Saputro \& Fathoni, 2017)

Berdasarkan dari berbagai penelitian yang telah dilakukan terdahulu mengenai etos kerja maka dapat diketahui bahwa etos kerja yang tepat dipengaruhi motivasi, bidaya, sosial politik, lingkungan, pendidikan, dan peforma karyawan. Dalam penelitian ini penulis bertujuan untuk menggambarkan etos kerja dan faktor-faktor yang memepengaruhi etos kerja Pegawai Kecamatan. Kecamatan Sidorejo merupakan lembaga pemerintahan dalam bidang pelayanan publik yang bertujuan untuk memberikan pelayanan kepada masyarakat. Dalam pengamatan penulis, penulis melihat fenomena dilapangan tentang etos kerja Pegawai Kecamatan Sidorejo Salatiga terdapat beberapa pagawai belum menyadari sepenuhnya tanggung jawab atas pekerjaan, kurang menghargai waktu kerja dalam hal ini masih terdapat pegawai terlambat masuk kantor, pulang sebelum jam kerja selesai, keluar kantor pada saat jam kerja dengan alasan pribadi, dan bahkan menjumpai ada masyarakat yang merasa layanan kantor tersebut lambat. Berdasarkan dari penjelasan latar belakang di atas menjadi suatu alasan bagi peneliti untuk meneliti "Gambaran Etos Kerja dan Faktor-faktor yang Memepengaruhi Etos Kerja Pegawai Kecamatan Sidorejo".

Berdasarkan latar belakang diatas persoalan penelitian ini yaitu: 1). Seperti apa gambaran etos kerja pagawai Kecamatan Sidorejo Salatiga? 2). Faktor-faktor yang mempengaruhi etos kerja Pegawai Kecamatan Sidorejo?

Tujuan dari penelitian ini yaitu: 1). Untuk menggambarkan etos kerja di Kecamatan Sidorejo Salatiga 2). Untuk mengidentifikasi faktor-faktor yang mempengaruhi etos kerja pegawai Kecamatan Sidorejo Salatiga.

Dengan adanya penelitian ini diharapkan dapat memberikan deskripsi baru, menambah wawasan, pengetahuan, informasi dan ilmu pengetahuan mengenai gambaran etos kerja dan faktor-faktor yang mempengaruhi etos kerja pada organisasi dan lembaga pemerintah dan memberikan deskripsi baru kepada pembaca sebagai acuan dalam mengembangkan penelitianpenelitian sejenis selanjutnya.

Untuk pegawai Kecamatan Sidorejo Salatiga diharapkan dapat memberikan gambaran dan fakror-faktor yang mempengaruhi dalam hal etos kerja serta sebagai masukan dan motivasi. Untuk Kecamatan Sidorejo penelitian ini bermanfaat bagi pihak Kecamatan sebagai pedoman untuk memperbaiki etos kerja karyawan. Untuk peneliti lain penelitian ini dapat dijadikan sebagai bahan masukan bagi yang ingin melakukan penelitian dengan mengangkat permasalahan yang sama.

Sinamo (2005) menyatakan bahwa etos kerja adalah seperangkat perilaku kerja positif yang berakar pada kedasaran yang kental, keyakinan yang fundamental, disertai komitmen yang total pada paradigma kerja yang integral. Paradigma berarti konsep utama kerja itu mencakup idealisme yang mendasari, prinsip- prinsip yang mengatur, nilai-nilai yang menggerakkan, sikap-sikap yang dilahirkan standarstandar yang hendak dicapai; termasuk karakter utama, pikiran dasar, kode etik, kode moral, dan kode perilaku bagi para pemeluknya.

Chaplin (2001) menyatakan bahwa etos kerja merupakan watak atau karakter suatu kelompok nasional atau kelompok rasial tertentu. Dalam suatu perusahaan etos kerja tidak dapat muncul dengan begitu saja, akan tetapi harus dilakukan dan ditangani dengan sungguh-sungguh melalui proses yang tepat dengan melibatkan semua karyawan sebagai sumber daya manusia dalam seperangkat sistem dan alat-alat pendukung.

Menurut Mathis \& Jackson (2006) etos kerja adalah totalitas kepribadian dirinya serta cara mengekspresikan, memandang, meyakini, dan memberi makna pada sesuatu yang mendorong dirinya untuk bertindak dan meraih amal yang optimal. Karyawan yang memiliki etos kerja yang baik akan berusaha menunjukkan suatu sikap, watak serta keyakinan dalam melaksanakan suatu pekerjaan dengan bertindak dan bekerja secara optimal.

Anogara (2009) mengatakan etos kerja merupakan suatu pandangan dan sikap suatu organisasi atau manusia dalam bekerja. Apabila bekerja dipandang sebagai suatu hal yang luhur bagi manusia. Maka individu dalam sebuah organisasi memiliki etos kerja yang cenderung tinggi begitupula sebaliknya jika individu memiliki sikap dan pandangan 
terhadap bekerja sebagai sesuatu yang bernilai rendah bagi kehidupan, maka etos kerja dengan sendirinya akan rendah.

Siagian (2007) menyatakan bahwa etos kerja merupakan norma-norma yang bersifat mengikat dan ditetapkan secara eksplisit serta praktek-praktek yang diterima sebagai suatu kebiasaan yang wajar untuk dipertahankan serta diterapkan dalam kehidupan kekayaan para anggota organisasi. Meningat nilai etos kerja yang terkandung ialah adanya unsur penilaian, maka penilaian itu digolongkan menjadi dua yaitu, penilaian yang secara positif dan negative.

Raharjo \& Widodo (2014) mengatakan etos kerja diartikan sebagai nilai kerja yang positif yang dimiliki seseorang dengan ciri-ciri seperti: kerja sebagai kewajiban moral dan religious, disiplin kerja yang tinggi dan kebanggaan atas hasil karyanya.

Berdasarkan uraian di atas maka dapat di simpulkan bahwa etos kerja merupakam seperangkat perilaku individu yang khas dalam memandang suatu pekerjaan sebagai kebiasaan yang wajar untuk diterapkan dalam pekerjaannya sehingga menjadi suatu ciri khas dalam meraih hasil yang optimal serta sebagai ajaran yang diyakini seseorang atau sekelompok orang tentang ajaran baik dan benar yang direalisasikan secara nyata dalam perilaku bekerja.

Aspek etos kerja menurut Titisari, Warso, dan Haryono (2016) kerja adalah rahmat, amanah, panggilan, aktualisasi, ibadah, seni, kehormatan, dan pelayanan.

Menurut pendapat Sinamo (2005) etos kerja memiliki tiga aspek atau karakteristik yang pertama keahlian interpersonal. Keahlian interpersonal merupakan aspek yang ada kaitannya dengan hubungan kerja dengan orang atau hubungan antar sesama pekerja di lingkungan kerjanya. Keahlian interpersonal meliputi sikap, kebiasaan, cara, penampilan dan perilaku yang dilakukan oleh individu saat berada dengan orang lain serta mempengaruhi cara individu berinteraksi dengan orang lain. Kedua yaitu inisiatif, insiatif sendiri diartikan sebagai karakteristik yang mendorong seseorang untuk lebih semangat dalam berkerja dan mengembangkan kinerjanya dan tidak mudah merasa puas jika kinerjanya dianggap biasa. Aspek ini dihubungkan dengan keadaan di tempat kerja yang tidak lancar. Dan yang ketiga dapat diandalkan, dapat diandalkan merupakan aspek yang berhubungan dengan adanya harapan terhadap hasil kerja dari pekerja dan merupakan perjanjian implisit pekerja untuk melaksanakan fungsi dalam berkerja. Para pekerja diharapkan bisa memuaskan harapan minimun perusahaan, tanpa adanya sikap yang berlebihan sehingga dalam berkerja yang bukan tugasnya. Aspek ini sangat diiginkan oleh perusahaan terhadap pekerjanya.

Menurut Tasmara (2002) menyatakan etos kerja inividu dapat diukur melalui menghargai waktu, keinginan untuk mandiri, penyesuaian, tangguh dan pantang menyerah.
Sedangkan
Rukmana
(2010), berpendapat aspek etos kerja adalah aspek dari dalam, aspek motif sosial, dan dan aspek persepsi.

Berdasarkan penjelasan para ahli tentang aspek-aspek di atas maka yang paling relevan untuk penelitian ini akan menggunakan teori aspek etos kerja dari (Titisari, Warso, \& Haryono, 2016) kerja adalah rahmat, amanah, panggilan, aktualisasi, ibadah, seni, kehormatan, dan pelayanan.

Indikator etos kerja menurut Siregar (2000) dalam Octarina (2013) terdiri atas kesadaran, semangat, inisiatif, kemauan, disiplin kerja, produktif, peningkatan dan wawasan.

Indikator etos kerja menurut salamun dalam Priharwantiningsih (2019) diantaranya kerja keras, disiplin, jujur, tanggung jawab, rajin, dan tekun.

Sedangkan Sinamo mengumukakan indikator etos kerja berupa kerja adalah rahmat, amanah, panggilan, aktualisasi, ibadah, seni, kehormatan, dan pelayanan.

Terdapat beberapa faktor yang mempengaruhi etos kerja karyawan dalam suatu perusahaan, (Winardi, 2007) menyatakan ada beberapa faktor yang dapat mempengaruhi etos kerja seseorang dalam bekerja yang pertama faktor kebijakan, meliputi adanya gaji yang dapat dirasakan sangat mensejahterakan. Yang kedua faktor imbalan, faktor imbalan ini dapat memotivasi karyawan untuk berprestasi dan bekerja keras. Yang ketiga faktor kultur, meski terlihat biasa faktor kultur dapat memberikan dampak besar dalam peningkatan motivasi kerja. Yang keempat faktor mental dari karyawan, jika karyawan dalam suatu perusahaan memiliki mental yang kuat maka karyawan tersebut akan tetap memiliki motivasi kerja meski ketiga faktor di atas kurang mendukung.

$\begin{array}{cccc}\text { Menurut } & \text { Yousef } & \text { (2000) } & \text { dalam } \\ \text { Octarina (2013) } & \text { faktor } & \text {-faktor yang }\end{array}$ memepengaruhi etos kerja adalah kerja keras, komitmen dan dedikasi terhadap pekerjaan, kreativitas selama bekerja, kerja sama serta persaingan di tempet kerja, ketepatan waktu dalam bekerja, keadilan, dan kedermawanan 
di tempat kerja. (Novliadi, 2009) menyatakan faktor-faktor yang mempengaruhi etos kerja diantaranya yaitu faktor agama, budaya, sosial politik, kondisi lingkungan atau geografis, pendidikan, struktur ekonomi, dan motivasi intrinsik individu.

Berdasarkan faktor-faktor yang mempengaruhi etos kerja diatas, faktor-faktor yang relevan bagi etos kerja pegawai Kecamatan Sidorejo Salatiga adalah faktor etos kerja yang dinyatakan oleh (Novliadi, 2009) yaitu faktor agama, budaya, sosial politik, kondisi lingkungan atau geografis, pendidikan, struktur ekonomi, dan motivasi intrinsik individu.

\section{METODE}

Penelitian ini dilakukan di Kecamatan Sidorejo Salatiga. Jenis penelitian dalam penelitian ini adalah penelitian deskriptif kualitatif yaitu penelitian yang datanya menggambarkan keadaan yang sebenarnya dan seadanya. Penelitian ini menggunakan objek Pegawai Kecamatan Sidorejo Salatiga. Populasi dalam penelitian ini seluruh pegawai Kecamatan Sidorejo Salatiga. Pengambilan sampel dari populasi tersebut menggunakan metode saturation sampling. Menurut (Sugiyono, 2005) sampling jenuh/saturation sampling merupakan jumlah dari semua populasi dijadikan sebagai sempel penelitian karena jumlah populasi yang sedikit. Dalam penelitian ini populasi penelitian berjumlah 14 orang maka semua populasi akan dijadikan sampel penelitian.

Teknik pengumpulan data dalam penelitian ini menggunakan teknik wawancara langsung dengan pihak yang terkait dengan menggunakan data primer berupa faktor-faktor yang mempengaruhi etos kerja pegawai Kecamatan Sidorejo Salatiga. Dalam penelitian ini data dianalisis dengan proses mencari dan menyusun data yang dihasilkan melalui wawancara, catatan lapangan, dan menggunakan analisis distribusu frekuensi dengan melihat faktor-faktor yang mempengaruhi etos kerja pegawai Kecamatan Sidorejo Salatiga.

\section{HASIL DAN PEMBAHASAN}

Berdasarkan wawancara yang telah peneliti lakukan untuk mengetahui gambaran dan faktor-faktor yang mempengaruhi etos kerja pegawai Kecamatan Sidorejo Salatiga, peneliti telah melakukan wawancara kepada seluruh pegawai Kecamatan Sidorejo Salatiga. Persoalan pertama membahas tentang pengertian etos kerja, pandangan responden tentang pekerjaan, penerapan etos kerja, dan pentingnya etos kerja. Persoalan kedua membahas tentang faktor-faktor yang mempengaruhi etos kerja. Berikut adalah penjelasan dari masing-masing persoalan

Kecamatan Sidorejo merupakan salah satu kecamatan yang berada di wilayah Kota Salatiga yang terletak di Jalan Ki Penjawi No.19, Sidorejo Lor, Sidorejo, Kota Salatiga, Jawa Tengah. Kecamatan Sidorejo berdiri dengan tujuan membantu masyarakat yang berada dalam lingkup kecamatan Sidorejo dalam mengurus administrasi yang berkaitan dengan kecamatan.

Kecamatan menpunyai visi yaitu "Mewujudkan pelayanan prima yang mudah, cepat dan mendukung pencapaian yang sejahtera mandiri dan bermartabat". Misi Kecamatan "Meningkatkan kualitas pelayanan publik, meningkatkan kompetensi aparatur, penguatan kelembagaan kemasyarakatan, dan optimalisasi kemitraan dengan stakeholder. Para pegawai merupakan sumber daya yang perlu dikelola akan menciptakan kualitas sumber daya yang kompeten dan dapat memberikan pelayanan yang prima kepada masyarakat. Salah satunya dengan menerapkan etos kerja dalam setiap pekerjaannya. Untuk mengetahui gambaran dan faktor-faktor yang mempengaruhi etos kerja pegawai yang ada di Kecamatan Sidorejo sendiri. Berikut adalah gambar struktur organisasi yang ada di Kecamatan Sidoreho Salatiga: 


\section{Struktur Organisasi Kecamatan Sidorejo}

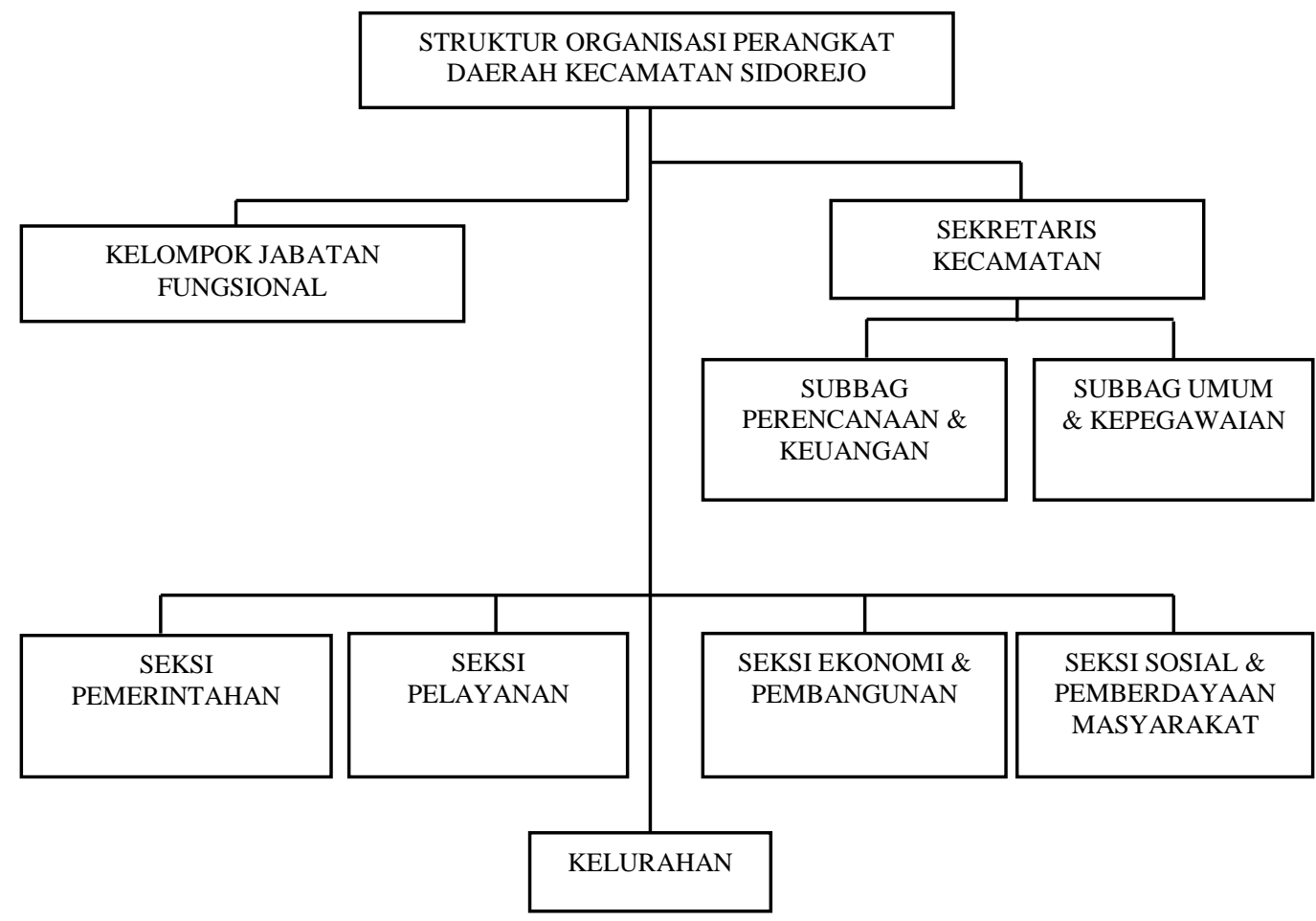

Sumber: Kantor Kecamatan Sidorejo, 2019

Kecamatan Sidorejo Salatiga memiliki sumber daya manusia sebanyak 14 orang dalam menjalankan kegiatan oprasionalnya sebagai instansi pemerintah dengan dikepalai oleh camat. sebagai pegawai negeri sipil Kecamatan Sidorejo Salatiga dituntut untuk memiliki etos kerja yang baik agar dapat mencapai tujuan utama dari entitas tersebut.

Dalam memperoleh data mengenai pemahaman terkait etos kerja, peneliti

Tabel 1. Pengertian Etos Kerja mewawancarai keseluruhan sumber daya manusia yaitu seluruh pegawai kecamatan Sidorejo Salatiga dengan mengajukan beberapa pertanyaan. Hasil dari wawancara dapat dilihat pada beberapa tabel berikut.

Terdapat empat pandangan mengenai pengertian etos kerja menurut pegawai Kecamatan Sidorejo Salatiga seperti pada Tabel 1 berikut.

\begin{tabular}{lll}
\hline No & Pengertian Etos Kerja & Jumlah \\
\hline 1. & Sikap & 6 \\
2. & Perilaku & 4 \\
3. & Karakter & 3 \\
4. & Norma atau Aturan & 1 \\
Jumlah & & 14 \\
\hline
\end{tabular}

Berdasarkan Tabel 1 di atas tentang pengertian etos kerja dapat dilihat bahwa ratarata pegawai Kecamatan Sidorejo Salatiga memberikan pendapat bahwa etos kerja merupakan suatu sikap individu karena ada enam karyawan yang mengatakan hal tersebut yang artinya etos kerja merupakan sikap yang muncul dari dalam individu untuk melaksanakan tugas dengan totalitas serta penuh tanggung jawab. Empat pegawai mengatakan sebuah perilaku karena dengan menerapkan perilaku kerja yang positif dapat meraih hasil yang positif dan optimal, sedangkan tiga pegawai yang lain mempunyai pendapat yang berbeda mengatakan etos kerja merupakan suatu karakter, dan satu pegawai mengatakan etos kerja merupakan norma atau aturanyang artinya dalam 
menjalankan pekerjaan harus sesuai dengan SOP yang ada. Sehingga dapat dikatakan etos kerja menurut pegawai Kecamatan Sidorejo merupakan suatu sikap tanggung jawab totalitas srta berkomitmen terhadap pekerjaan yang dilakukan setiap harinya. Seperti yang telah di ungkapkan oleh beberapa informan berikut ini:

Informan enam: "Suatu sikap kerja yang positif seperti tanggung jawab totalitas dalam melaksanakan tugas, sikap tersebut mencul atas kehendak dan kesadaran diri".

Tabel 2. Pandangan Responden Tentang Pekerjaan
Informan sepuluh: "Seperangkat perilaku kerja positif yang berakar pada kesadaran yang disertai dengan komitmen".

Informan sembilan: "Karakter dari dalam hati individu yang mendasari semangat kerja agar meraih hasil yang maksimal...".

Informan empat belas: "merupakan sebuah norma dalam suatu instansi agar para karyawan bekerja sesuai dengan SOP atau norma yang berlaku".

Terdapat tiga pandangan mengenai suatu pekerjaan menurut pegawai Kecamatan Sidorejo Salatiga seperti pada Tabel 2 berikut.

\begin{tabular}{lll}
\hline No & Pandangan Tentang Pekerjaan & Jumlah \\
\hline 1. & Kewajiban & 9 \\
2. & Sarana mencari nafkah & 5 \\
3. & lbadah & 4 \\
Jumlah & & 18 \\
\hline
\end{tabular}

Sumber: Hasil Penelitian, 2019

Berdasarkan Tabel 2 di atas tentang pandangan responden tentang pekerjaan terdapat tiga pandangan. Yang pertama, pekerjaan merupakan suatu kewajiban ada sembilan informan mengatakan hal tersebut karena pada umumnya pekerjan adalah suatu kewajiban yang wajib kita lakukan atas pekerjaan yang kita terima serta dilakukan dengan senang hati dan tanggung jawab agar menghasilkan output yang maksimal. Lima informan mengatakan pekerjaan adalah sarana untuk mencari nafkah karena dengan melakukan pekerjaan kita akan mendapatkan gaji untuk memenuhi kebutuhan. Empat pegawai mengatakan pekerjaan merupakan suatu ibadah sehari-hari dan menjaga kelangsungan hidup dan empat pegawai mengatakan pekerjaan merupakan suatu ibadah. Meski terdapat tiga pandangan yang berbeda, namun rata-rata pegawai mengatakan bahwa pekerjaan merupakan suatu kewajiban karena merupakan hal yang positif jika karyawan menganggap sebagai kewajiban dengan demikian pegawai akan merasa pekerjaan yang dilakukannya setiap hari sebagai tanggung jawab mau atau tidak harus tetap dikerjakan serta pegawai akan melakukan yang terbaik agas jasanya terus digunakan oleh entitas tersebut. Hal tersebut sama dengan yang diungkapkan oleh beberapa informan sebagai berikut:

Informan dua: "Saya memandang suatu pekerjaan sebagai kewajiban yang harus kita laksanakan secara sungguh-sungguh dan penuh tanggung jawab. Amanah yang diberikan kepada kita harus dilaksanakan dengan senang hati dan tanggung jawab".

Informan dua belas: "Pekerjaan merupakan salah satu kegiatan mencari uang untuk kelangsungan hidup manusia yang harus dijlankam umtuk mendapatkan upah dari pekerjaan tersebut sehingga dapat mempertahankan kelangsungan hidup". Infoeman tujuh: "hmm, saya memandang pekerjaan sama halnya dengan beribadah yang harus kita lakukan setiap hari dengan ikhlas agar mendapatkan manfaat gitu mbak".

Terdapat empat pandangan mengenai penerapan etos kerja pegawai di Kecamatan Sidorejo Salatiga seperti pada Tabel 3 berikut

Tabel 2. Penerapan Etos Kerja Pegawai Kecamatan

\begin{tabular}{lll}
\hline No & Penerapan Etos Kerja di Kecamatan Sidorejo & Jumlah \\
\hline 1. & Saling bekerja sama dengan rekan kerja & 3 \\
2. & Memberikan pelayanan yang prima kepada masyarakat & 9 \\
3. & Melakukan apel pagi dan sore untuk kedisiplinan & 7 \\
4. & Membuat laporan kerja harian & 5 \\
Jumlah & $\mathbf{2 4}$ \\
\hline
\end{tabular}

Sumber: Hasil Penelitian, 2019 
Berdasarkan Tabel 3 di atas tentang penerapan etos kerja pegawai Kecamatan Sidorejo Salatiga, dapat dilihat bahwa pegawai Kecamatan Sidorejo rata-rata mengatakan bahwa penerapan etos kerja memberikan pelayanan yang prima kepada masyarakat terdapat sembilan pegawai yang mengatakan hal tersebut yang artinya sebagai suatu instansi pemerintah yang memiliki tugas memberi pelayanan jasa pegawai perlu memberikan pelayanan yang prima kepada masyarakat yang mengalami kesulitas dalam mengurus administasi. Tujuh pegawai mengatakan melakukan apel pagi dan sore tujuan diadakannya kegiatan tersebut agar para pegawai tidak datang terlambat dan untuk melatih kedisiplinan, lima pegawai mengatakan membuat laporan kerja harian dari kegiatan tersebut pegawai dapat mengetahui apa saja yang telah dikerjakan dan di kerjakan yang belum dalam satu hari itu. Sedangkan tiga pegawai mengatakan saling bekerja sama dengan rekan kerja hal tersebut dapat meringankan beban satu dengan lainnya. Artinyakegiatan yang sering dilakukan sebagai bentuk penerapan etos kerja adalah memberikan pelayanan yang prima kepada masyarakat hal tersebut selaras dengan misi kecamatan Sidorejo Salatiga. Seperti yang telah diungkapkan oleh beberapa informan berikut:

Informan 12: "kalau penerapan etos kerja disini, para pekerja saling bekerja sama dalam hal pekerjaan serta memberikan pelayanan yang maksimal kepada masyarakat".

Informan 13: "Etos kerja pegawai Kecamatan Sidorejo sudah baik. Penerapan etos kerja di bidang pelayanan sebagai tugas utama Kecamatan Sidorejo...".

Informan tujuh: "Mengadakan apel pagi dan sore untuk melihat kedisiplinan para pegawai dan membuat hasil kerja dalam bentuk laporan harian apa saja yang telah dilakukan".

Informan 14: "penerapan etos kerja di sini, para pegawai di sini mempunyai kegiatan yang saya rasa positif seperti melakukan apel pagi dan sore serta membuat laporan harian".

Terdapat tiga pandangan mengenai seberapa penting etos kerja yang dimiliki karyawan dalam bekerja menurut pegawai Kecamatan Sidorejo Salatiga seperti pada Tabel 4 berikut.

Tabel 3. Penting Etos Kerja Dimiliki Karyawan Dalam Bekerja

\begin{tabular}{lll}
\hline No & Pentingnya Etos Kerja & Jumlah \\
\hline 1. & Penting, untuk dijadikan pedoman dalam bekerja & 9 \\
2. & Penting, sebagai tolok ukur hasil kerja & 3 \\
3. & Penting, sebagai sarana peningkatan karir & 4 \\
Jumlah & & 16 \\
\hline
\end{tabular}

Sumber: Hasil Penelitian, 2019

Berdasarkan Tabel 4 di atas tentang pentingnya etos kerja pegawai Kecamatan Sidorejo terdapat tiga pandangan. Yang pertama etos kerja berperan penting untuk dijadikan sebagai pedoman dalam bekerja ada sembilan pegawai yang mengatakan hal tersebut karena pada umumnya seorang karyawan yang baik akan memiliki pedoman dalam bekerja untuk bertindak secara objektif. Tiga informan mengatakan etos kerja penting sebagai tolok ukur hasil kerja dan empat informan mengatakan etos kerja penting sebagai sarana peningkatan karir dengan menerapan nilai-nilai yang terkandung dalam etos kerja maka pegawai dapat enikkankan karir yang lebig bagus dari sebelumnya. Meski terdapat tiga pandangan yang berbeda, namun rata-rata mengatakan bahwa etos kerja penting dimiliki karyawan untuk "dijadikan pedoman dalam bekerja" karena merupakan hal yang positif seperti bisa mengatur waktu dengan baik atas tanggung jawanya serta membuat bekerja lebih efektif dan efisien. Hal tersebut sama dengan yang diungkapkan oleh beberapa informan berikut.

Informan satu: "Sangat penting, nilai-nilai yang terkandung dalam etos kerja dapat di jadikan pedoman dalam bekerja seperti pemanfaatan waktu kerja yang efektif, tanggung jawab, dan rajin".

Informan 13: "Dijadikan sebagai tolak ukur hasil kerja seseorang. Etos kerja yang tinggi akan menjadikan tingkat efisiensi dalam melakukan pekerjaan tinggi pula".

Informan enam: "Sangat penting jika etos kerja dimaknai dan diterapkan nilai-nilai yang terdandung didalamnya dapat menjadikan seseorang memiliki kepribadian yang terus berkembang dalam bekerja atau untuk mengembangkan karir yang lebih bagus".

Ada delapan faktor yang mempengaruhi etos kerja karyawan. Seperti yang terlampir dalam tabel 4.5 berikut. 
Tabel 4. Faktor-Faktor yang Mempengaruhi Etos Kerja

\begin{tabular}{lllllllll}
\hline & Gaji & Agama & Disiplin & $\begin{array}{l}\text { Tingkat } \\
\text { Sosial } \\
\text { Politik }\end{array}$ & $\begin{array}{l}\text { Kondisi } \\
\text { Lingkungan }\end{array}$ & $\begin{array}{l}\text { Tingkat } \\
\text { Pendidikan }\end{array}$ & $\begin{array}{l}\text { Struktur } \\
\text { Ekonomi }\end{array}$ & Motivasi \\
\hline $\begin{array}{l}\text { Mempengaruhi } \\
\text { Tidak }\end{array}$ & 12 & 8 & 14 & 4 & 10 & 12 & 9 & 10 \\
$\begin{array}{l}\text { Mempengaruhi } \\
\text { Jumlah }\end{array}$ & 2 & 6 & 0 & 10 & 4 & 2 & 5 & 4 \\
\hline & 14 & 14 & 14 & 14 & 14 & 14 & 14 & 14 \\
\hline
\end{tabular}

Berdasarkan hasil wawancara terkait dengan faktor-faktor yang mempengaruhi etos kerja dapat dilihat pada tabel 4.5 di atas tentang faktor-faktor yang mempengaruhi etos kerja terkait dengan gaji, pegawai rata-rata mengatakan gaji memepengaruhi etos kerja artinya dengan diberikannya gaji yang sesuai dengan maka pegawai akan bekerja lebih giat dan semangat. Terkait dengan agama, pegawai mengatakan agama mempengaruhi etos kerja. Agama merupakan suatu pedoman bagi individu, mlihat hal tersebut maka agama juga dijadikan pedoman dalam bertindak dan melakukan pekerjaan dalam bekerja. Dilihat dari disiplin, pegawai mengatakan bahwa disiplin mempengaruhi etos kerja pegawai kecamatan. Dengan adanya penerapan disiplin yang tegas akan membangun kebiasaan pegawai yang diharapkan oleh suatu entitas. Untuk tingkat sosial politik ratarata pegawai mengatakan tingkat sosial politik tidak mempengaruhi etos kerja karena aparatur sipil negara diperbolehkan untuk berpolitik tetapi tidak diperbolehkan untuk mendukung salah satu partai atau calon.

Untuk faktor yang mempengaruhi etos kerja terkait dengan Kondisi lingkungan menurut para pegawai kecamatan mempengaruhi etos kerja, dengan kondisi lingkungan yang nyaman, bersih, damai dapat membuat kerja menjadi tenang dan fokus terhadap pekerjaan. Untuk tingkat pendidikan menurut para pegawai Kecamatan Sidorejo mempengaruhi etos kerja. Dengan adanya jenjang pendidikan lebih tinggi antar sesama rekan kerja dapat memperbaiki jenjang karir pegawai tersebut. Pandangan pegawai Kecamatan Sidorejo Salatiga tentang faktorfaktor yang mempengaruhi etos kerja terkait dengan struktur ekonomi, pegawai rata-rata mengatakan struktur ekonomi memepengaruhi etos kerja. Faktor-faktor etos kerja terkait dengan motivasi, rata-rata pegawai Kecamatan Sidorejo mengatakan motivasi mempengaruh etos kerja, dengan diberikannya motivasi dari atasan, keluarga, dan rekan kerja akan memberikan semangat kerja lagi, movivasi yang diberikan tersubut sebagai bentuk dukungan.

\section{SIMPULAN DAN SARAN}

Berdasarkan hasil analisis dan pembahasan di atas dapat ditarik kesimpulan antara lain: Pendangan tentang etos kerja menurut pegawai Kecamatan Sidorejo Salatiga merupakan suatu sikap seseorang dalam melakukan pekerjaannya dengan baik ikhlas serta bertanggung jawab terhadap pekerjaannya akan menghasilkan output yang maksimal.

Terkait dengan faktor-faktor yang mempengaruhi etos kerja, terdapat tujuh faktor yang mempengaruhi dari delapan faktor dan terdapat satu faktor yang kurang mempengaruhi etos kerja pegawai kecamatan yaitu tingkat sosial politik karena pegawai kecamatan merasa bahwa tingkat tingkat sosial politik kurang berpengaruh bahkan dapat dikatakan tidak berpengaruh karena sebagai pegawai negeri sipil diperbolehkan untuk memberikan hak suaranya untuk memilih tetapi tidak diperbolehkan jika mendukung atau berpolitik.

Hasil dari penelitian ini dapat memberikan informasi mengenai gambaran dan faktor-faktor yang mempengaruhi etos kerja yang ada di Kecamatan Sidorejo Salatiga. Lebih fokus penelitian ini melihat faktor-faktor yang mempengaruhi etos kerja pegawai yang ditinjau dari faktor gaji, faktor agama, faktor disiplin, faktor sosial politik, kondisi lingkungan, tingkat pendidikan, struktur ekonomi, dan faktor motivasi. Hal-hal yang dapat diimplementasikan agar pegawai mempunyai etos kerja tinggi diantaranya yaitu: dari faktor agama, dengan agama dijadikan sebagai pedoman hidup atau melakukan sesuatu hal memungkinkan pegawai memiliki etos kerja yang tinggi kemudian di terapkan dalam pekerjaannya, kondisi lingkungan dengan membuat lingkungan kerja bersih, 
nyaman, dan menambah fasilitas yang dibutuhkan agar dapat menunjang pekerjaan. Selanjutnya berkaitan dengan faktor motivasi dengan adanya motivasi dari atasan, rekan kerja serta keluarga memungkinkan pegawai memiliki etos kerja tinggi guna untuk melakukan pekerjaannya. Hal di atas tentunya dapat mendukung etos kerja pegawai guna mewujudkan situasi yang diinginkan oleh semua pihak.

\section{Implikasi Teoritis}

Penelitian ini menunjukkan bahwa pegawai Kecamatan Sidorejo memiliki hasil yang berbeda dengan penelitian yang dilakukan (Novliadi, 2009) bahwa faktor yang mempengaruhi etos kerja adalah agama, gaji, sosial politik, kondisi lingkungan, tingkat pendidikan, struktur ekonomi, motivasi. Namun dalam penelitian ini disiplin mempengaruhi etos kerja serta untuk tingkat sosial politik di Kecamatan Sidorejo tidak terlalu berpengaruh terhadap etos kerja.

Penelitian ini memiliki keterbatasan yang dapat dipertimbangkan dalam penelitian berikutnya yaitu data dalam penelitian ini diperoleh melalui wawancara sabaiknya diperoleh juga melalui pengamatan, serta dalam penelitian ini hanya menggunakan teori faktor-faktor yang mempengaruhi etos kerja dari beberapa ahli karena penelitian ini kekurangan literature yang berkaitan dengan penelitian sehingga peneliti kekurangan sumber informasi.

Dengan adanya beberapa kekurangan dalam penelitian ini, penulis ingin memberikan saran untuk penelitian mendatang menggunakan beberapa teori lain tentang faktor-faktor yang mempengaruhi etos kerja guna menambah wawasan, objek penelitian tidak hanya pegawai kecamatan tetapi masyarakat juga, serta hasil penelitian ini agar dapat dijadikan acuan informasi untuk melakukan penelitian lain yang mengangkat tentang topik yang sama.

\section{DAFTAR PUSTAKA}

Anoraga, P. (2009). Manajemen Bisnis Modern . Jakarta: Rineka Cipta.

Chaplin , J. (2001). Kamus Psikologi. Bandung: CV. Pionir Jaya.

Indriani, W. (2015). Kontriusi Etos Kerja Islami Terhadap Kinerja Dosen. Jurnal Manajemen Pendidikan Islam, 173-188.
Karauwan, R., Lengkong, V. P., \& Mintardjo, C. (2015). Pengaruh Etos Kerja, Budaya Organisasi, dan Beban Kerja Terhadap Kinerja Pegawai di Dinas Pekerjaan Umum Minahasa Selatan. Jurnal Emba, 1196-1207.

Mathis , R., \& Jackson, J. (2006). Manajemen Sumber Daya Manusia . Jakarta: Salemba Empat.

Novliadi, F. (2009). Hubungan Antara Organization-Based Self-Estem Dengan Etos Kerja. USU e-Respository, 1-28.

Octarina , A. (2013). Pengaruh Etos Kerja dan Disiplin Kerja Terhadap Kinerja Pegawai Pada Dinas Kebudayaan Pariwisata Pemuda Dan Olahraga Kabupaten Sorolangun. Jurnal Manajemen, 1-15.

P., A. (2009). Manajemen Bisnis Modern . Jakarta: Rineka Cipta.

Priharwantiningsih, A. (2019). Analisis Manajemen Sumber Daya Manusia, Kepemimpinan Kepala Sekolah, Budaya Organisasi dan Etos Kerja pada Sekolah Menengah . Media Manajemen Pendidikan , 84-93.

Raharjo, E. P., \& Widodo, P. B. (2014). Hubungan Kepuasan Terhadap Gaji Dengan Etos Kerja Karyawan KPRI di Kota Semarang. Jurnal Universitas Doponegoro, 1-10.

Rahma, S., Suhandana, G., \& Suarni, N. K. (2013). Kontribusi Efektivitas Kepemimpnan, Budaya Organisasi, dan Etos Kerja Terhadap Kepuasan Kerja Pegawai Balai Diklat Keagamaan Denpasar . Jurnal Universitas Pendidikan Ganesha, 1-12.

Rukmana, W. (2010). Analisis Pengaruh Human Relation dan Kondisi Fisik Lingkungan Terhadap Etos Kerja dan Kinerja. Jurnal Universitas Diponegoro.

Saputa, R. A., Lengkong , V. P., \& Trang, I. (2018). Analisis Penerapan Etos Kerja Pada Perangkat Desa Kemanga Dua Kecamatan Tompaso. Jurnal Emba, 698707.

Saputro, G. A., \& Fathoni, A. (2017). Analisis Pengaruh (Human Relation/ Hubungan Antar Manusia) dan Kondisi Fisik 
Lingkungan Kerja Terhadap Etos Kerja dan Kinerja Karyawan PT Karunia Adijaya Mandiri Semarang. Jurnal Universitas Pandanaran, 1-9.

Sinamo, J. (2005). Delapan Etos Kerja Profesional: Navigator Anda Menuju Sukses. Jakarta: Institut Darma Mahardika.

Sinamo, J. (2011). Etos Kerja Profesional Navigator Anda Menuju Sukses. Jakarta: PT Spirit Mahardika.

Sugiyono. (2005). Memahami Penelitian Kualitatif. Bandung: Alfabeta.

Sutrisno. (2009). Manajemen Sumber Daya Manusia. Jakarta: Kencana Pernada Media Grup.

Tampubolon, B. D. (2007). Analisis Faktor Gaya Kepemimpinan dan Faktor Etos Kerja Terhadap Kinerja Pegawai Pada Organisasi yang telah menerapkan SNI 19-9001-2001. Jurnal Standardisasi, 106115.

Tasmara, K. T. (2002). Membudayakan Etos Kerja Islami. Jakarta: Gema Insani Pers.

Titisari, Warso, M., \& Haryono, A. T. (2016). Analisis Pengaruh Karakteristik Organisasi, Etos Kerja dan Disiplin Kerja Terhadap Performa Perusahaan dengan Efektifitas Kinerja Karyawan sebagai Variabel Intervening (Studi kasus pada PT Indofood Semarang). Journal of Management, 1-47.

Winardi, J. (2007). Motivasi dan Permotivasian Dalam Manajemen. Jakarta: Raja Grafindo Persada. 